\title{
On Proteins of Gastric Cancer
}

\section{Biological Properties of the Protein Fractions*}

\author{
By
}

\section{Azuma Masukawa}

(铔川束)

From the Medico-chemical Institute (Director: Prof. H. Masamune) and the Surgical Clinic of Prof. M. Muto, Tohoku University, Sendai

(Received for publication, February 3, 1953)

The protein fractions, Preps. I, II and III, of gastric cancers and human gastric mucosa in the foregoing reports ${ }^{1 / 2}$ ) were further examined regarding their biological properties such as hemoagglutination inhibition, precipitin reaction with the immune sera, hemolytic activity and skin reaction.

\section{Experiments And Comments}

Preps. I and II were the fractions both insoluble in glacial acetic acid but precipitable and unprecipitable respectibly by acid, and Prep. III the fraction soluble in glacial acetic acid ( $\mathrm{S}$. the 1st report).

Anti-hemoagglutinative force. Inhibition of hemoagglutination was examined by our usual procedure ( $\left.\mathrm{Cf} . \mathrm{Oh}-\mathrm{Uti}^{3}\right)$. The anti-O serum, prepared by injection of $\mathrm{O}$ erythrocytes to a goat, was diluted 10 times and absorbed with Be erythrocytes. Thus treated, it agglutinated $\mathrm{O}$ erythrocytes at a dilution of $1: 4 \times 10^{2}$ but Be erythrocytes only faintly. The consequences of the assay are shown in Tables I-II. The fractions of Group A cancers were all specifically group active but were weaker than the corresponding fractions of Group A mucosa. Prep. III from Group $\mathrm{O}$ cancer was also less anti-agglutinative than that from the mucosa of the same blood group.

Precipitin reaction with the rabbit antisera of the cancer (Group B), gastric mucosa (Group $O$ ) and placenta. ${ }^{4}$ (he rabbit antisera, kindly supplied by Dr. Kobayasi, ${ }^{5}$ ) were absorbed with normal human serum of Group AB ( 2 drops per cc.) prior to the assay. The results are illustrated in Table III.

Preps. I's from the cancers and gastric mucosa reacted to equal extents with either of the anti-cancer and anti-mucosa sera, although

\footnotetext{
* The 8th report of Masamune and coworkers' "On Proteins and Amino Acids."
} 

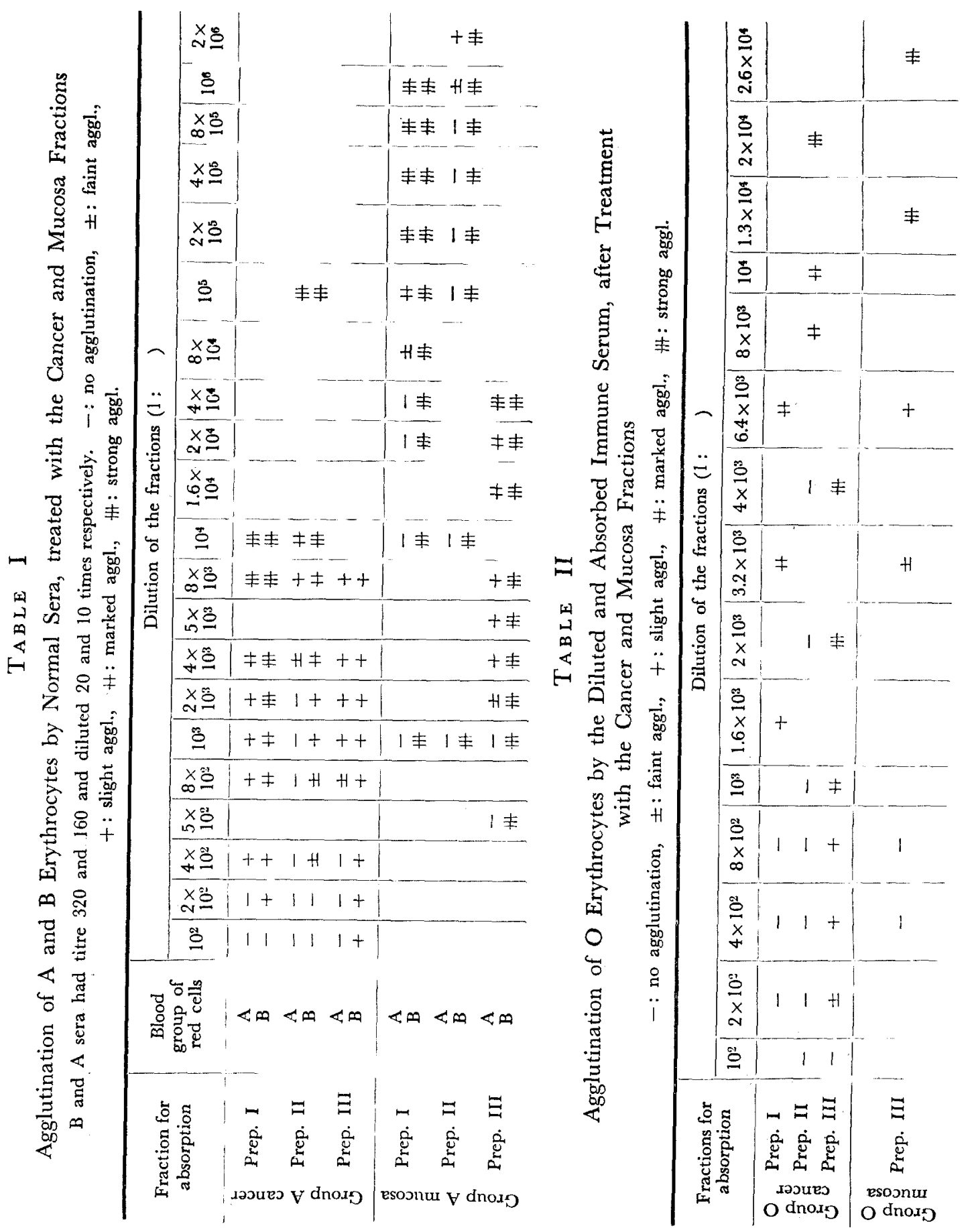
TAB LE III

Precipitin Reaction (Ring Test) of the Preparations from Cancers and Gastric Mucosa with the Immune Rabbit Sera absorbed with Normal Human Serum

-: no precipitation, \pm : faint precip., + : definite precip.

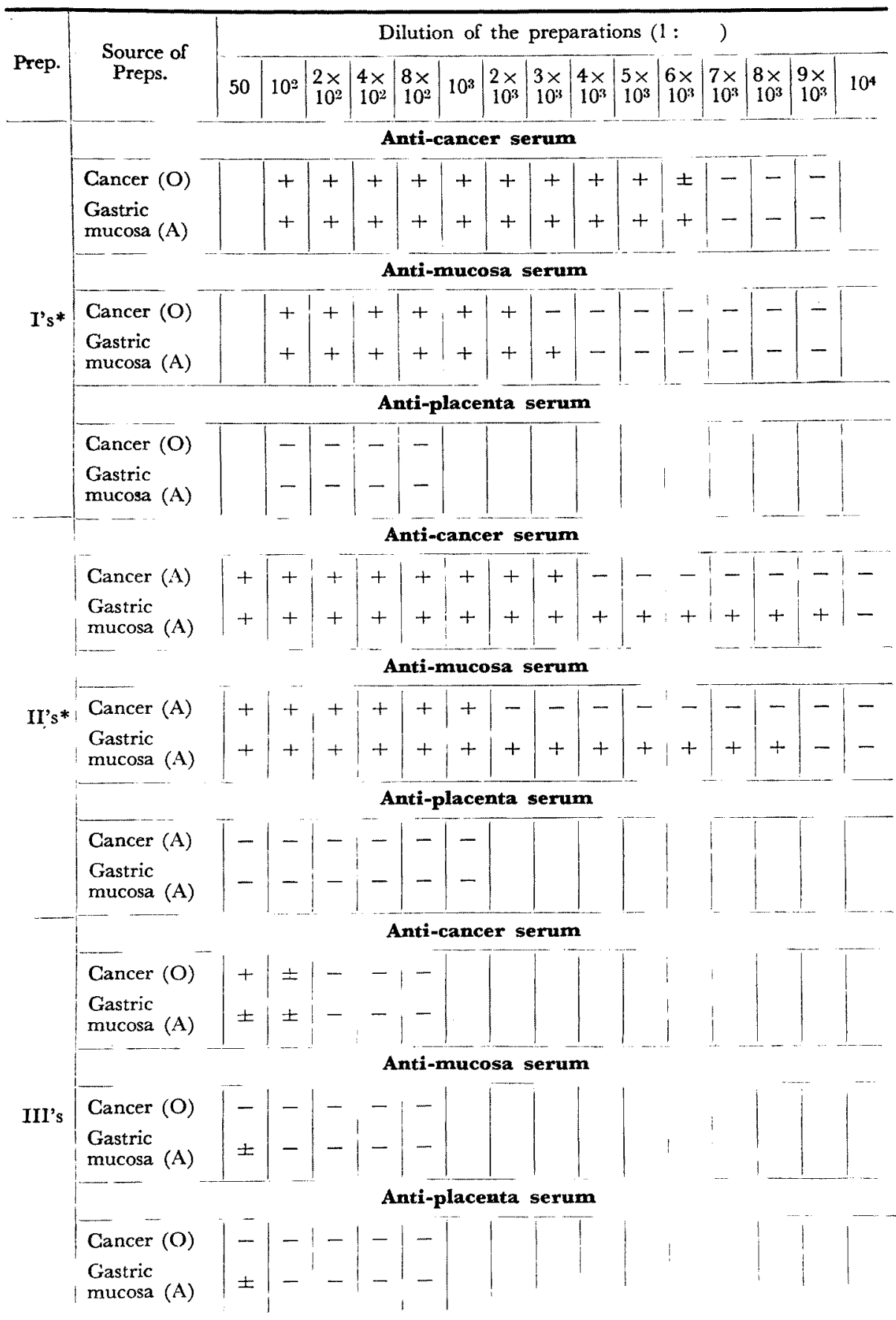

* The substance was dissolved in physiological saline by the aid of a small quantity inf $\mathrm{NaOH}$ 
these sera showed marked discrepancy of potency on their side. Contrariwise, Prep. II from the cancers (Group A) was less reactive to those sera than the corresponding preparation from stomach mucosa. However, the former substance gave a precipitate with the anti-cancer serum even after complete absorption with the latter. Namely, the less reactive one of the pair of the preparations did not have the perfectly same specificity in reaction that the other had. That these preparations gave different electrophoretic patterns (the 2nd report) may have some connection with this finding. In this regard a detailed study will be reported later from this Institute. The antibody of Prep.-III's in the antisera were too minute for revealing a definite fact, and, moreover, the results obtained with the anti-placenta serum showed absence of reactive antidodies.

Hemolysis. A $0.5 \%$ solution of Preps. II's and III's from the gastric cancers and mucosa (both of persons of Group A) were prepared, and to $0.5 \mathrm{cc}$. each of the original and progressively diluted solutions were added 2 drops of a $3 \%$ erythrocyte (Group O) suspension. The mixtures were stood in a $37^{\circ} \mathrm{C}$ thermostat for 3 hrs., shaking at intervals of 30 minutes. Table IV shows the results. In the controls, in which the solutions were substituted with physiological saline, no hemolysis occurred.

The fractions from gastric cancers looked to be entirely or almost inert. Those from normal gastric mucosa effected hemolysis but as slightly as may be ascribed to a contaminant.

Cancer skin reaction. A $0.56 \%$ solution of the preparations were prepared, employing sterile physiological saline, with slight alkalization for dissolution of the substance and subsequent neutralization when necessary, and a $1 / 9$ volume of $5 \%$ phenol added. The original solutions thus obtained were diluted appropriately with the saline and phenol solution before use. After 5 hours from the intracutaneous injection of a $0.2 \mathrm{cc}$.

TABLE IV

Occurrence of Hemolysis by Preps. II's and III's

- : no hemolysis, \pm : faint hemol., + : partial hemol., H: half hemol., H: nearly complete hemol.

\begin{tabular}{|c|c|c|c|c|c|c|c|c|c|}
\hline \multirow[b]{2}{*}{ Prep. } & \multirow[b]{2}{*}{ Source of Preps. } & \multicolumn{6}{|c|}{ Dilution of the preparations ( 1 : } & \multicolumn{2}{|l|}{ ) } \\
\hline & & $\begin{array}{c}2 \times \\
10^{2}\end{array}$ & $\begin{array}{l}4 \times \\
10^{2}\end{array}$ & $\begin{array}{l}8 \times \\
10^{3}\end{array}$ & $\begin{array}{l}2 \times \\
10^{3}\end{array}$ & $\begin{array}{l}4 \times \\
10^{3}\end{array}$ & $\begin{array}{l}8 \times \\
10^{3}\end{array}$ & $\begin{array}{l}2 \times \\
10^{4}\end{array}$ & $\begin{array}{l}4 \times \\
16^{4}\end{array}$ \\
\hline \multirow{2}{*}{ II's" } & Cancer (A) & - & - & - & - & - & - & - & - \\
\hline & Gastric mucosa (A) & + & \pm & - & - & - & - & - & - \\
\hline \multirow{2}{*}{ III's } & Cancer (A) & \pm & - & - & - & - & - & - & - \\
\hline & Gastric mucosa (A) & $H$ & + & - & - & - & - & - & - \\
\hline
\end{tabular}

* The substance was dissolved in physiol. saline by the aid of a minute quantity of $\mathrm{NaOH}$. 
Fig. 1

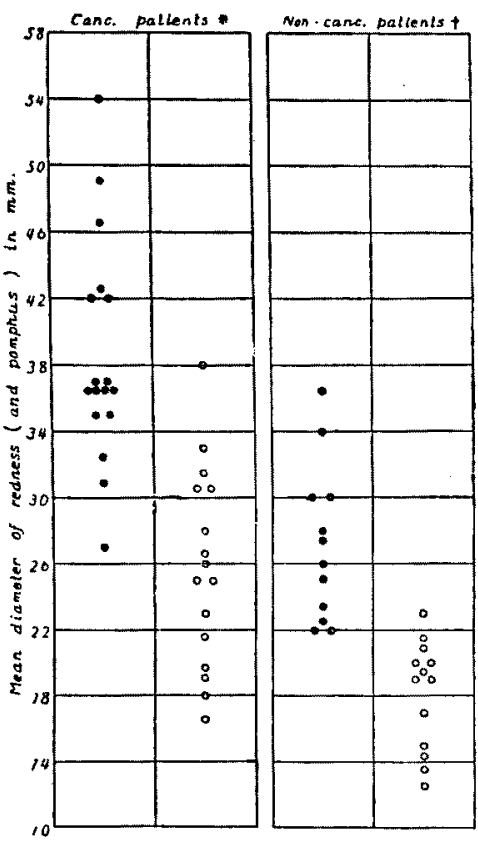

Fig. 2

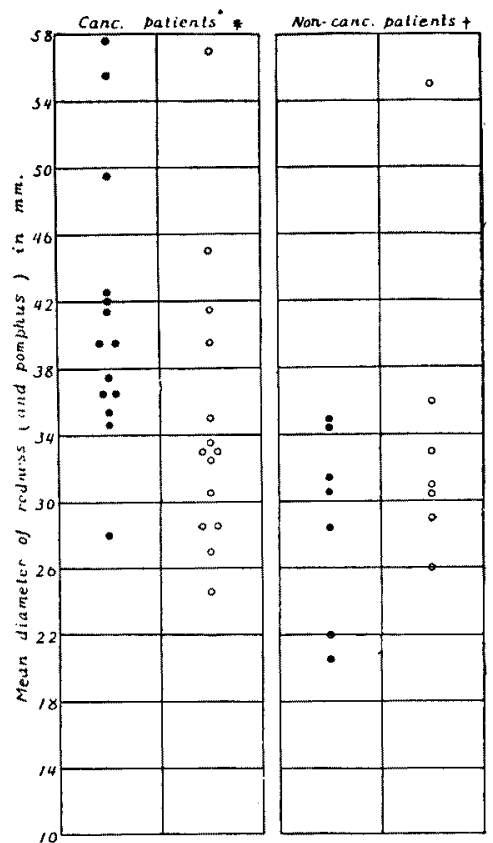

Fig. 1. Showing the results of the skin test with Prep.-I's from gastric cancers (Group O) and gastric mucosa (Group A) (both diluted to $0.1 \%$ ).

- the cancer substance. O the mucosa substance. * carcinoma of oesophagus (1), stomach (3), uterus (7), pancreas (2), tongue (1), biliary ducts (1), and liver (1), and osteosarcoma (1). † haemangioma (1), appendicitis (1), enteroptosis (1) and gastric or duodenal ulcer (9).

Judgement: the cancer substance, positive; the mucosa substance, positive.

Fig. 2. Showing the results of the skin test with Prep.-II's from gastric cancers and gastric mucosa both of Group A. Dilution of the substances $0.1 \%$.

- the cancer substance. O the mucosa substance. * carcinoma of stomach (7), liver (2), pancreas (2), rectum (1), oesophagus (1) and biliary ducts (1). † gastric ulcer (2), fracture (1), tuberculosis of kidney (1), tuberculous pleuritis (1), haemorrhoids (1) and chronic pancreatitis (1).

Judgement: the cancer substance, positive; the mucosa substance, positive (not distinct).

portion on the inner side of forearm, the longest and shortest diameters of the redness and pomphus were measured and their total sum divided with 4 (When no pomphus appeared, the sum of diameters of the redness was divided with 2). Figs. 1-3 show the average diameters thus obtained in cancerous and non-cancerous patients.

It may be asserted therefrom that the preparations from gastric cancers give generally a larger redness and pomphus in the former group of 


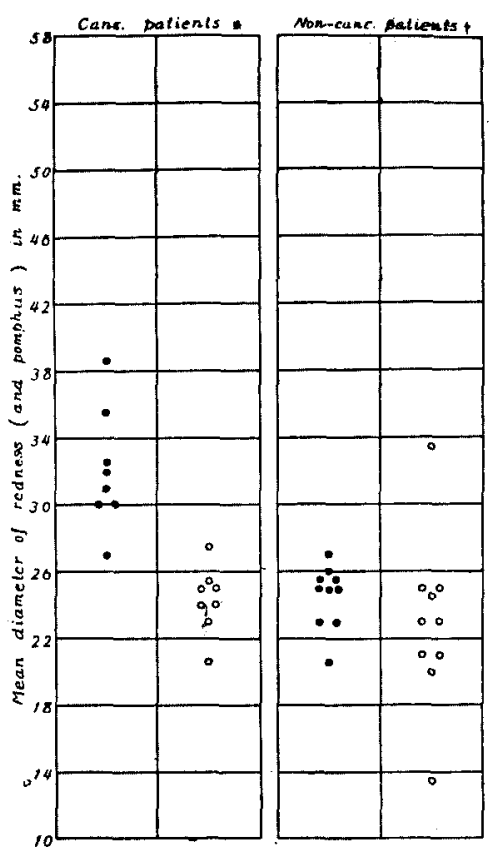

Fig. 3. Showing the results of the skin test with Prep.-III's from gastric cancers of Group $\mathrm{O}$ and gastric mucosa of Group A (both diluted to $0.1 \%$ ).

- the cancer substance. o the mucosa substance. * carcinoma of stomach (4), mamma (1), rectum (1) and submaxillary g!and (2). + gastric or duodenal ulcer (10).

Judgement: the cancer substance, positive; the mucosa substance, negative.

patients than in the latter. The preparations from gastric mucosa also showed some such tendency but gave smaller spots.

Effect of tryptic digestion on the precipitin and cancer skin reaction of the preparations. 1) Digestion. A weighed amount (15-30 mg.) of a preparation and an equal amount or more of trypsin (Kahlbaum) were taken up in water (50 to 250 volumes) and after addition of a $1 \% \mathrm{Na}_{2} \mathrm{CO}_{3}$ solution to $\mathrm{pH} 9.0$ and two drops of toluene, placed in an incubator at $37^{\circ} \mathrm{C}$. $\mathrm{pH}$ of the mixture was readjusted every $12 \mathrm{hrs}$. to the original, until it ceased to change. Then the digestate was neutralized with a $1 \% \mathrm{HCl}$ solution and heated, as stoppered with cotton, in a boiling waterbath for 10 minutes.

2) Precipitin reaction of the digestates with immune rabbit sera (anti-Group B cancer and anti-Group O mucosa serum) prepared as the ones used above. For the present purpose, Preps. I's from Group O 
TABLE V

Precipitin Reaction of the Digestate of Preps. I's from Group O

Gastric Cancers and Group A Mucosa together with that of the Undigested Materials with an Anti-cancer and an Antimucosa Rabbit Sera absorbed with Human Serum

(Group AB)

The mixtures incubated for digestion, $10 \mathrm{mg}$. Prep. I and $10 \mathrm{mg}$. trypsin in 1 cc. of water; duration of incubation, 14 days. - : no precipitin reaction, + : occurrence of the reaction.

\begin{tabular}{|c|c|c|c|c|c|c|c|c|c|c|}
\hline \multirow[b]{2}{*}{ Antigen from } & \multicolumn{10}{|c|}{ Dilution of antigens ( 1 : } \\
\hline & $10^{2}$ & $\begin{array}{l}2 \times \\
10^{2}\end{array}$ & $\begin{array}{l}4 \times \\
10^{2}\end{array}$ & $\begin{array}{l}8 \times \\
10^{2}\end{array}$ & $10^{3}$ & $\begin{array}{l}2 \times \\
10^{3}\end{array}$ & $\begin{array}{l}3 \times \\
10^{3}\end{array}$ & $\begin{array}{l}4 \times \\
10^{3}\end{array}$ & $\cdots$ & $10^{4}$ \\
\hline \multicolumn{11}{|c|}{ Anti-cancer serum } \\
\hline \multirow{4}{*}{$\begin{array}{l}\text { Group } \mathrm{O} / \begin{array}{l}\text { digested } \\
\text { cancer }\end{array} \\
\text { Group Aigest. } \\
\text { mucosa }\left\{\begin{array}{l}\text { digested } \\
\text { undigest. }\end{array}\right.\end{array}$} & + & + & + & + & + & - & - & - & - & - \\
\hline & + & + & + & + & + & + & - & - & $\rightarrow$ & - \\
\hline & + & + & + & + & + & + & - & - & - & - \\
\hline & + & + & + & + & + & + & - & - & - & - \\
\hline \multicolumn{11}{|c|}{ Anti-mucosa serum } \\
\hline \multirow{4}{*}{$\begin{array}{l}\text { Group } \mathrm{O}\left\{\begin{array}{l}\text { digested } \\
\text { cancer } \\
\text { undigest. }\end{array}\right. \\
\text { Group A }\left\{\begin{array}{l}\text { digested } \\
\text { mucosa }\end{array}\right.\end{array}$} & + & + & + & + & - & - & - & - & - & - \\
\hline & + & + & + & + & - & - & - & - & - & - \\
\hline & + & + & + & + & - & - & - & - & - & - \\
\hline & + & + & + & + & + & - & - & - & - & - \\
\hline
\end{tabular}

TABLE VI

Precipitin Reaction of the Digestate of Preps. II's from Group A

Gastric Cancer and Group A Mucosa together with that of the Undigested Materials with the Absorbed Anti-cancer and Anti-mucosa Sera in Table V

The mixture incubated for digestion, $15 \mathrm{mg}$. Prep. II $+15 \mathrm{mg}$. trypsin in $1.5 \mathrm{cc}$. water; duration of incubation, 18 days. - : no precipitin reaction, + : occurrence of the reaction.

\begin{tabular}{|c|c|c|c|c|c|c|c|c|c|c|c|c|}
\hline \multirow[b]{2}{*}{ Antigen from } & \multicolumn{12}{|c|}{ Dilution of antigens (1: } \\
\hline & $10^{2}$ & $\cdots$ & $\begin{array}{l}8 \times \\
10^{2}\end{array}$ & $10^{3}$ & $\begin{array}{l}2 \times \\
10^{3}\end{array}$ & $\begin{array}{l}3 \times \\
10^{3}\end{array}$ & $\begin{array}{l}4 \times \\
10^{3}\end{array}$ & $\cdots$ & $\begin{array}{l}8 \times \\
10^{3}\end{array}$ & $\begin{array}{l}9 \times \\
10^{3}\end{array}$ & $10^{4}$ & $\begin{array}{l}1.2 \\
\times 10^{4}\end{array}$ \\
\hline \multicolumn{13}{|c|}{ Anti-cancer serum } \\
\hline \multirow{4}{*}{$\begin{array}{l}\begin{array}{l}\text { Group A } \\
\text { cancer }\end{array}\left\{\begin{array}{l}\text { digested } \\
\text { undigest. }\end{array}\right. \\
\text { Group A }\left\{\begin{array}{l}\text { digested } \\
\text { mucosa }\end{array}\right.\end{array}$} & + & + & + & + & + & + & - & - & - & - & - & - \\
\hline & + & + & + & + & + & + & - & - & - & - & - & - \\
\hline & + & + & + & + & + & + & + & + & + & + & - & - \\
\hline & + & + & + & + & + & + & + & + & + & + & + & - \\
\hline
\end{tabular}

Anti-mucosa serum

\begin{tabular}{|c|c|c|c|c|c|c|c|c|c|c|c|c|}
\hline \multirow{2}{*}{$\begin{array}{l}\text { Group A } \\
\text { cancer }\end{array}\left\{\begin{array}{l}\text { digested } \\
\text { undigest. }\end{array}\right.$} & - & - & - & - & - & - & - & - & - & - & - & - \\
\hline & + & + & + & $-\cdots$ & - & - & - & - & - & $\sim$ & - & - \\
\hline \multirow{2}{*}{$\begin{array}{l}\text { Group A digested } \\
\text { mucosa }\end{array}$} & + & + & + & + & $\div$ & + & 4 & + & + & - & - & - \\
\hline & + & + & $-\frac{1}{-1}$ & + & + & + & + & + & + & + & - & - \\
\hline
\end{tabular}


TABLE VII

Precipitin Reaction of the Digestate of Preps. III's from Group A

Gastric Cancer and Group A Mucosa together with that of the Undigested Materials with the Anti-cancer and Anti-mucosa Sera in Table V

The mixture incubated for digestion, $30 \mathrm{mg}$. Prep. III $+35 \mathrm{mg}$. trypsin in $1.5 \mathrm{cc}$. water; duration of incubation, 30 days. - : no precipitin reaction, $t$ : occurrence of the reaction.

\begin{tabular}{l}
\hline Antigen from \\
\hline
\end{tabular}

gastric cancers and Group A gastric mucosa and Preps. II's and III's from Group A gastric cancers and Group A gastric mucosa were subjected to digestion. Tables V-VII illustrate the results by the digestates together with those by the undigested materials.

The digestate of Preps. I's and II's showed generally as strong precipitin reaction as the undigested, except when the digestate of Prep. II of the cancers (Group A) was laid over the anti-mucosa serum, which is difficult to explain without a further study. Regarding Preps. III's, the sera were too weakly reactive with them as such to draw any conclusion from the negative reaction of these specimens after digestion.

3) For the skin test a part of the digestates above were diluted to $0.1-0.05 \%$ with physiological saline and a $5 \%$ phenol solution as above, and the technique of the assay above was also followed. The results are diagrammatically expressed in Figs. 4-6. It was revealed that the digestion had not destroyed the structure giving the cancer reaction at all.

\section{SUMmary}

1. In iso- and homologous hemoagglutination-inhibition, the protein 
Fig. 4

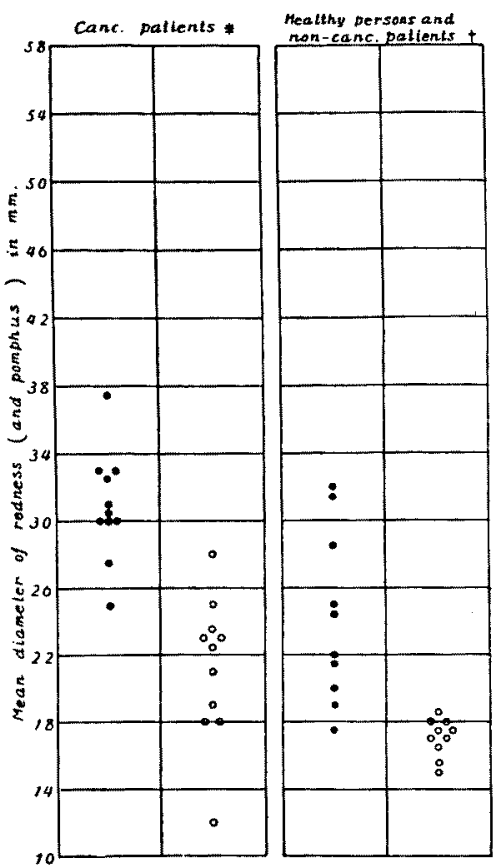

Fig. 5

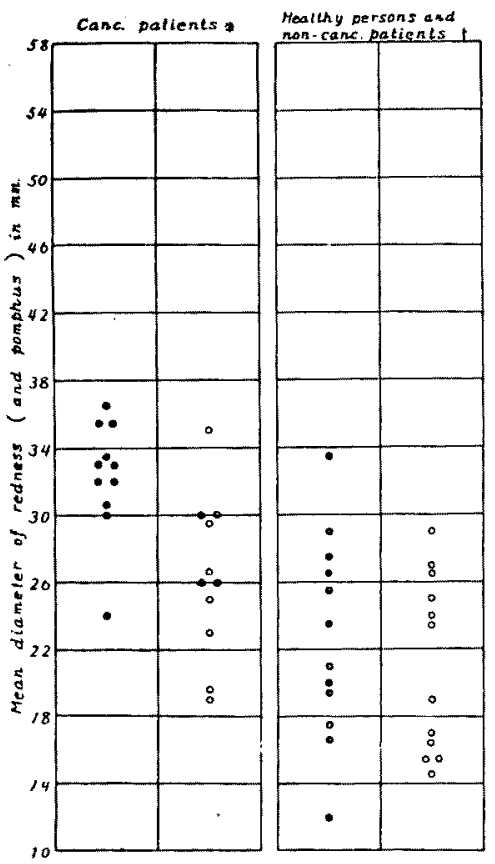

Fig. 4. Showing the skin reaction with the digestate of the materials which gave the results in Fig. 1.

The digestates were diluted for the test as much as the undigested.

- the digestate of the cancer substance. o the digestate of the mucosa substance. * carcinoma of stomach (2), maxillary antrum (2), oesophagus (1), gall bladder (1), biliary ducts (1), liver (1), pancreas (1) and mamma (1), and sarcoma (1). † healthy persons (2), hernia (1), gastric ulcer (2) and duodenal ulcer (5).

Judgement: the digestate of the cancer substance, positive; the digestate of the mucosa substance, positive.

Fig. 5. Showing the skin reaction with the digestate of the materials which gave the results in Fig. 2. The digestates were diluted for the test to $0.05 \%$.

- the digestate of the cancer substance. o the digestate of the mucosa substance. * carcinoma of stomach (2), maxillary antrum (2), oesophagus (1), gall bladder (1), biliary ducts (1), liver (1), pancreas (1) and mamma (1), and sarcoma (1). + healthy persons (5), duodenal ulcer (4), gastric ulcer (2) and hernia (1).

Judgement: the digestate of the cancer substance, positive; the digestate of the mucosa substance, positive (not so distinct).

fractions of $\mathrm{A}$ and $\mathrm{O}$ gastric cancers were less potent than the corresponding protein preparations from gastric mucosa of respectively same blood groups. 


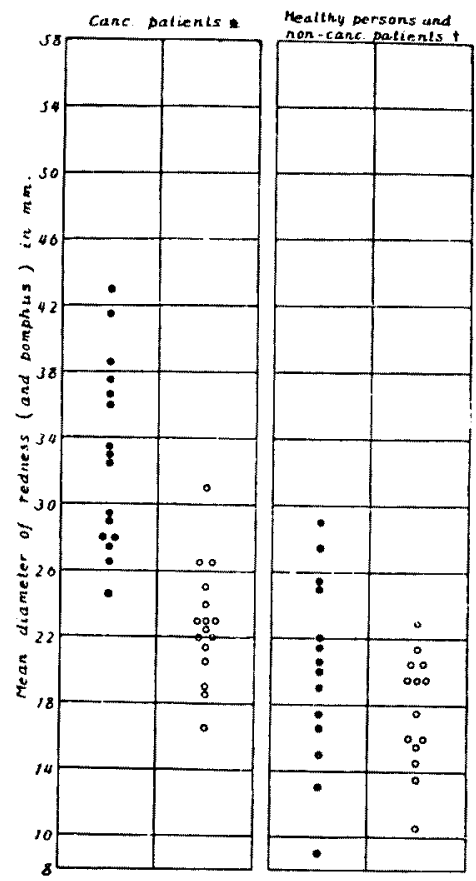

Fig. 6. Showing the skin reaction with the digestate of the materials which gave the results in Fig. 3 (both diluted to $0.1 \%$ ).

- the digestate of the cancer substance. o the digestate of the mucosa substance. * carcinoma of mamma (4), rectum (2), uterus (2), stomach (1), maxillary antrum (1) and tongue (1), and sarcoma (5). † healthy persons (9), gastric ulcer (1), haemorrhoids (1), anal fistula (1), cholelithiasis (1) and vesical papilloma.

Judgement: the digestate of the cancer substance, positive; the digestate of the mucosa substance, positive.

2. As to the precipitin reaction with anti-cancer and anti-gastric mucosa rabbit sera, the preparations indicated that immunological divergency existed in at least some pairs of the corresponding proteins from the two sources.

3. In respect with the hemolytic power, the preparations from the both kinds of tissue appeared to be nearly devoid of it.

4. The cancer substances proved more powerful in giving cancer skin reaction than the corresponding mucosa substances, although both groups of the preparations had this potency, of which they were not deprived by trypsin.

5. Taken altogether, the stomach cancer proteins are not regarded identical with the corresponding proteins of stomach mucosa from the biological view point too (Cf. the foregoing report). 


\section{References}

1) Masukawa, Tohoku J. Exp. Med., this volume, p. 251.

2) Masukawa, ibid., this volume, p. 261.

3) Oh-Uti, ibid., 1949, 51, 302.

4) The immune sera were obtained by injection of the physiological saline tissue extracts.

5) Cf. Kobayasi, K., Tohoku J. Exp. Med., in press. 